\title{
O DISCURSO ASCÉTICO EM MICHEL FOUCAULT E DESCARTES
}

\author{
THE ASCETIC SPEECH IN MICHEL FOUCAULT AND DESCARTES
}

Cláudia Maria Martins*

\section{RESUMO}

No texto "Mon corps, ce papier, ce feu", de 1972, Michel Foucault apresenta uma leitura das Meditações Metafísicas de Descartes na qual identifica uma dupla trama: um discurso demonstrativo guiado pela ordem das razões e um discurso ascético orientado pelo exercício performativo de criação do sujeito de conhecimento. Este artigo mostra que, neste raro momento em que Foucault se colocou no papel de comentador de um texto filosófico, os aspectos realçados no texto cartesiano são igualmente emblemáticos de seu próprio método filosófico. Particularizando-se pelo apontamento de visíveis e enunciáveis, as histórias foucaultianas também perfazem uma dupla trama e incitam uma espécie de ascese.

PALAVRAS-CHAVE: Foucault. Descartes. Meditações metafísicas. Subjetividade. História da loucura.

\section{ABSTRACT}

In the text "Mon corps, ce papier, ce feu", written in 1972, Foucault identifies in Descartes's Meditations a double weft: a demonstrative discourse guided by the order of reasons and an ascetic discourse guided by the performatic exercise of creating the subject of knowledge. The present research has showed that, in such a rare moment when Foucault puts himself in the role of a commentator of a philosophical text, the highlighted aspects in the Cartesian text are equally emblematic of his own philosophical method. Characterized by pointing out the visible and the enunciable, Foucault's histories also make up a double weft and encourage a kind of ascesis.

KEYWORDS: Foucault. Descartes. Metaphisical meditations. Subjectivity. History of madness.

\footnotetext{
* Professora de Filosofia na UNIFAI - Centro Universitário Assunção, instituição associada à PUC-SP.
} 


\section{INTRODUÇÃO}

O conteúdo deste artigo é parte integrante de nossa tese de doutorado que teve por objetivo reconstituir aspectos fundamentais da filosofia de Michel Foucault a partir de uma célula problemática inscrita em Histoire de la folie à l'âge classique. Ali já se encontrava o germe da leitura foucaultiana das Meditações Metafísicas cartesianas que, na década de 196070, provocaria certa polêmica e debates entre os intérpretes de Descartes, dentre eles, o filósofo Jacques Derrida. A discussão suscitada entre este último e Foucault, dá origem ao texto "Mon corps, ce papier, ce feu", de 1972, no qual Foucault explicita esta leitura identificando no texto das Meditações uma dupla trama: um discurso demonstrativo guiado pela ordem das razões cartesianas e um discurso ascético, uma sequência de exercícios que visam a criação de um sujeito. Apresentamos neste artigo elementos que permitem aproximar o método que Foucault empreende, especialmente na elaboração de Histoire de la folie à l'âge classique, e a estratégia discursiva identificada pelo filósofo no discurso meditativo cartesiano, ou seja, pretende-se mostrar que os elementos que Foucault faz realçar em sua análise do texto cartesiano são emblemáticos de seu próprio método.

\section{Discurso meditativo: ordem das razões e ordem da ascese}

Embora nosso objetivo neste artigo não seja o de percorrer os momentos argumentativos do debate que se estabeleceu com Derrida, mas utilizar os momentos deste para evidenciar os aspectos da leitura foucaultiana das Meditações Metafísicas, para não corrermos o risco de tornar algumas passagens incompreensíveis, faz-se necessário restituir brevemente alguns momentos da querela.

Cerca de dois anos após a publicação da tese de Foucault, Jacques Derrida, que fora aluno de Foucault na École Normale Supérieur de Paris, pronuncia no Collège Philosophique de Jean Wahl a conferência "Cogito e História da loucura". a qual dá origem a um artigo publicado ainda naquele ano na Revue de Métaphysique et de Morale. Na ocasião, Derrida tece uma dura crítica ao que ele denominou "leitura ingênua" das Meditações cartesianas.

1 A conferência será publicada naquele ano na Revue de Métaphysique et de Morale, oct./déc., n.4, p. 460-494. Também constará mais tarde da coletânea de textos de Derrida L'écriture et la différence, de 1967. A tradução brasileira deste texto encontra-se no livro organizado por Maria Cristina Franco FERRAZ "Três tempos sobre a história da loucura", p. 11-67, além de constar da versão brasileira de $A$ escritura e a diferença, São Paulo: Perspectiva, 1979. 
Foucault já se inclinara na direção de comentar a análise de Derrida, contudo, a oportunidade de concretizá-la surge de maneira casual, em 1971, quando a Revista de Filosofia japonesa Paidéia intenta lançar uma edição especial dedicada à relação filosofia-literatura. A revista escolhe uma série de artigos para este número e submete a proposta aos autores. Dentre os artigos, figura "Cogito e História da loucura", de Jacques Derrida e "O discurso de Foucault e a escrita de Derrida", do estudioso japonês Y. Miyakawa. Ao perceber que a comparação entre as duas démarches seria um dos focos da edição, Foucault propõe a troca de um de seus textos por uma resposta que ele pretende elaborar ao artigo de Derrida. Esta resposta sairia na Revista japonesa Paideia, sob o título "Michel Foucault, Derrida e no Kaino" (FOUCAULT, 2001b).

Um ano depois, em 1972, Foucault publica uma versão um pouco modificada desta resposta no posfácio da segunda edição francesa de sua tese História da loucura, sob o título "Mon corps, ce papier, ce feu". Este é um dos poucos textos, e o mais longo do gênero, em que Foucault se coloca no papel de comentador ou intérprete de um texto filosófico. Este exercício a que se propõe oferece ao leitor a grata surpresa de ler uma análise rigorosa e detida, feita no mesmo estilo vigoroso e sedutor com que ele apresenta a sua filosofia.

Mas a história deste debate tem início 11 anos antes quando, em História da loucura, Foucault escolhe iniciar o capítulo central "Le Grand Renfermement", passo central de sua tese, com estas palavras: “A loucura, cujas vozes a Renascença acaba de libertar, cuja violência porém ela já dominou, vai ser reduzida ao silêncio pela Era clássica através de um estranho golpe de força" (FOUCAULT, 1978, p. 45).

O estranho "coup de force" a que alude Foucault refere-se à passagem da primeira meditação cartesiana onde, ao início do exercício da dúvida, Descartes cogita a hipótese de estar louco. Como se sabe, no movimento anterior, Descartes, movido pelo propósito de duvidar daquilo que lhe toca, daquilo que seus sentidos testemunham, e tendo assumido que estes já lhe enganaram algumas vezes sobre coisas muito pequenas ou distanciadas, questionava a si próprio sobre a possibilidade de negar o que lhe parece tão manifesto:

E como poderia eu negar que estas mãos e este corpo sejam meus? A não ser, talvez, que eu me compare a esses insensatos, cujo cérebro está de tal modo perturbado e ofuscado pelos negros vapores da bile que constantemente asseguram que são reis quando são muito pobres; que estão vestidos de ouro e de púrpura quando estão inteiramente nus; ou imaginam ser cântaros ou ter um corpo de vidro. Mas quê? São loucos e eu não seria menos extravagante se me guiasse por seus exemplos. (DESCARTES, 1975, p. 94). 
No contexto da história foucaultiana, a recusa de Descartes em comparar-se aos loucos antes de submeter-se à prova dos sonhos simbolizou, por meio deste "coup de force", o gesto que silenciaria a loucura na passagem do final da Renascença ao início do Período Clássico. A menção do texto cartesiano numa suposta História da loucura foi gesto polêmico, incompreendido, sujeito a inúmeras interpretações, uma vez que parece colocar um discurso filosófico relacionado a um acontecimento histórico singular.

No que toca à questão cartesiana, a crítica de Derrida pode ser sintetizada da seguinte maneira: em primeiro lugar, ela dirige-se ao fato de Foucault afirmar que Descartes teria inaugurado um novo entendimento da loucura a partir do Período Clássico, em segundo, critica o procedimento de Foucault de ter dissociado a loucura do contexto dos argumentos dos erros dos sentidos e dos sonhos, dando-lhe autonomia através da alegação da impossibilidade de submetê-la à prova da dúvida.

Sendo assim, Derrida procede a uma análise do texto cartesiano, à luz da interpretação de Guéroult, para provar que Descartes não somente não dissociou a loucura dos argumentos da ilusão dos sentidos e do sonho, como ao contrário, a re-introduziu através da hipótese do gênio maligno, entendida por ele como a possibilidade da loucura total. Derrida afirma que o argumento do sonho representou a radicalização da dúvida natural, a dúvida hiperbólica. $\mathrm{O}$ objetivo deste argumento era provar que temos motivos para duvidar mesmo das nossas representações sensíveis que nos pareçam mais indubitáveis. Assim, a certeza que resistisse ao sonho, também resistiria à sua respectiva ilusão em vigília. (DERRIDA, 2001).

Seja em "Mon corps, ce papier, ce feu" ou em "Resposta a Derrida", Foucault quer provar a vinculação da questão da loucura ao argumento do sonho, não ao gênio maligno. Derrida insiste na hipótese de que o argumento do sonho foi introduzido porque trazia desafios epistemológicos maiores que as fantasias dos delirantes, daí ele dizer que representava a exasperação hiperbólica da hipótese da loucura. Foucault trabalha a relação entre sonho e loucura a partir de alguns pontos. Em primeiro lugar, nos chama atenção ao vocabulário empregado em cada um dos parágrafos. Naquele da loucura, o termo principal seria compare, sendo, o louco, o elemento exterior ao qual se compara o meditador, e em contraposição, o parágrafo do sonho traria o "vocabulário da memória" (FOUCAULT, 1972, p. 588), atestando que não se trata agora de elemento exterior, mas do apego à experiência possível. A diferença também é marcante em relação aos cenários evocados por Descartes: no caso da loucura, como se sabe, transportam-se os loucos para uma outra cena, ao passo que 
aos sonhadores, a imagem memorizada é a mesma da situação em que o meditador se encontra.

Foucault nos convida a ver um processo de criação de uma contraposição que se dará no momento em que a ordem demonstrativa encontra ou cruza a ordem da ascese. A contraposição que, segundo Foucault, foi pensada por Descartes, dá-se entre o sujeito que medita e o sujeito que duvida, cada qual associada a uma ordem discursiva. Na contraposição embaralham-se as formas, elas cruzam-se numa espécie de quiasma, entendido aqui como uma metáfora visual para simbolizar o cruzamento entre planos distintos, cria-se uma espécie de contradição, que no entanto, é necessária, para que se crie o efeito desejado. Entendamos a contraposição, o efeito e a contradição no interior do jogo abaixo.

Foucault diz que o silogismo prático realizado por Descartes teve como conclusão desconfiar do testemunho dos sentidos. $\mathrm{O}$ argumento dos sonhos e da loucura são chamados para operar esta generalização e para levar mais longe o exercício da dúvida. Como se eles introduzissem duas respostas diferentes para a mesma questão: "para me decidir a duvidar de tudo, devo me desqualificar como razoável?" (FOUCAULT, 1972, p. 595). Afinal, é bem verdade que, "há coisas [sensíveis] das quais não se pode razoavelmente duvidar" (DESCARTES, 1975, p. 94), diria o sujeito que medita. Dá-se a passagem, o cruzamento entre as duas formas discursivas. Neste ponto, Foucault pergunta "Mas qual é portanto o obstáculo, o ponto de resistência do exercício da dúvida?” (FOUCAULT, 1972, p. 595). Não é outra coisa que aquilo que toca o meditador, sua situação imediata, aquilo que lhe está manifesto, que ele pode pensar com clareza e distinção, o vivo e o próximo em contraponto aos objetos distanciados que não podem ser vistos com distinção. Os loucos, assim como o sujeito que quer duvidar, negam o seu entorno imediato, seu corpo, mas não é preciso ser louco para duvidar, pode-se seguir adiante no exercício da dúvida, e pensá-la como uma dúvida razoável quando se lembra de ter tido ilusões semelhantes sonhando, por isso exclui-se a loucura, pois as qualificações do sujeito duvidando e do sujeito meditando não são possíveis no momento. A impossibilidade de ser louco é mostrada também pela sua caracterização, aquele que está com outras roupas (vestido de púrpura), outro corpo (cabeça de vidro). "Descartes marcou as cartas do jogo", o meditador estava ali junto ao fogo, "o louco está alhures" (FOUCAULT, 1972, p. 595).

A prova do sonho, por sua vez, é tão possível que o meditador passa a considerá-la de imediato. Note-se que ele não elenca sonhos delirantes mas a própria situação vivida na 
meditação. Existe uma contraposição inclusive semântica, do louco que está ausente e do sonho como algo que faz parte da minha existência rotineira humana. Foucault compara as reiteradas apreensões do meditador sobre o sonho quando diz que costuma dormir, costuma sonhar, lembra-se de ter sonhado, já sonhou que estava ali na mesa, sonhou que estava ali e tinha nítida impressão de não estar sonhando dada a vivacidade que lhe pareciam ter as impressões. Estas disposições são análogas aos momentos em que se evocam os elementos que compõem o aqui e agora do meditador em contraponto à situação dos loucos ausentes. Vejamos:

\begin{abstract}
Mas, ainda que os sentidos nos enganem às vezes, no que se refere às coisas pouco sensíveis e muito distantes, encontramos talvez muitas outras, das quais não se pode razoavelmente duvidar, embora as conhecêssemos por intermédio deles: por exemplo, [1] que eu esteja aqui, sentado junto ao fogo, vestido com um chambre, tendo este papel entre as mãos e outras coisas desta natureza. E como poderia eu negar que estas mãos e este corpo sejam meus? A não ser, talvez, que eu me compare a esses insensatos, cujo cérebro está de tal modo perturbado e ofuscado pelos negros vapores da bile que constantemente asseguram que são reis quando são muito pobres; que estão vestidos de ouro e de púrpura quando estão inteiramente nus; ou imaginam ser cântaros ou ter um corpo de vidro. Mas quê? São loucos e eu não seria menos extravagante se me guiasse por seus exemplos.

Todavia, devo aqui considerar que sou homem e, por conseguinte, que tenho o costume de dormir e de representar, em meus sonhos, as mesmas coisas, ou algumas vezes menos verossímeis, que esses insensatos em vigília. Quantas vezes ocorreume sonhar, durante a noite, que [2] estava neste lugar, que estava vestido, que estava junto ao fogo, embora estivesse inteiramente nu dentro de meu leito? Parece-me agora que não é com olhos adormecidos que [3] contemplo este papel; que esta cabeça que eu mexo não está dormente; que é com desígnio e propósito deliberado que estendo esta mão e que a sinto: o que ocorre no sono não parece ser nem tão claro nem tão distinto quanto tudo isso. Mas, pensando cuidadosamente nisso, lembro-me de ter sido muitas vezes enganado, quando dormia, por semelhantes ilusões. E, detendo-me neste pensamento, vejo tão manifestamente que não há quaisquer indícios concludentes, nem marcas assaz certas por onde se possa distinguir nitidamente a vigília do sono, que me sinto inteiramente pasmado: e meu pasmo é tal que é quase capaz de me persuadir de que estou dormindo.

Suponhamos, pois, agora, que estamos adormecidos e que todas essas particularidades, a saber, que [4] abrimos os olhos, que mexemos a cabeça, que estendemos as mãos, e coisas semelhantes, não passam de falsas ilusões; e pensemos que talvez nossas mãos, assim como todo nosso corpo, não são tais como os vemos. Todavia, é preciso ao menos confessar que as coisas que nos são representadas durante o sono são como quadros e pinturas, que não podem ser formados senão à semelhança de algo real e verdadeiro; e que assim, pelo menos, [5] essas coisas gerais, a saber, olhos, cabeça, mãos e todo o resto do corpo, não são coisas imaginárias, mas verdadeiras e existentes. (DESCARTES, 1975, p. 94, negritos nossos).
\end{abstract}

Os elementos corpo, papel, fogo, mãos ou afins são repetidos nada menos que cinco vezes. Na primeira, o meditador tem a certeza imediata de estar ali; na segunda, a cena é

Sapere aude - Belo Horizonte, v. 7 - n. 12, p. 85-100, Jan./Jun. 2016 - ISSN: 2177-6342 
reproduzida como um sonho que tantas vezes teve; na terceira, comparando a clareza das representações no sonho e na realidade; na quarta, a cena é evocada pelo meditador fazendo de conta que sonha; e por fim, na quinta menção, ele admite que mesmo se sonhando, é preciso admitir que estas ilusões do sonho, neste caso, são formadas a partir de coisas existentes. E propositalmente destacados desta imagem aparecem os loucos em seus corpos de vidros, e por isso Foucault pode afirmar que "as duas provas se opõem; uma que constituiu o sujeito como razoável (em face do louco desqualificado), e a outra que constituiu o sujeito duvidando (na indistinção entre sonho e vigília)" (FOUCAULT, 1972, p. 597). Então, após o exercício do sonho, tem-se dois efeitos, o salvamento do aqui e agora e a exclusão da loucura.

Vale lembrar que ascese, como nos informa Hadot, vem do termo grego áskesis e significa exercício, algo que se pratica (HADOT, 1999, p. 273). Portanto, em primeiro lugar, asceses são "práticas" que têm por finalidade causar alguma modificação em quem as pratica. A resposta à pergunta de Foucault requer que se compreenda o sentido da modificação pretendida por estas práticas. É interessante o parentesco semântico entre áskesis e a própria palavra meditação. Foucault nos lembra que o termo latino meditatio (FOUCAULT, 2004, p. 428-429) traduz o substantivo grego meléte, do verbo meletân, que significa treinar, exercitarse em algo, num tipo de exercício indefinidamente reiterável. E qual a relação da ascese com a criação de imagens? As imagens criam lugares.

A função da criação do lugar é muito clara: "instaurar o lugar desta operação" (FABRE, 1991, p. 11). Com efeito, o sentido geral da tese de Inácio de Loyola, descrita por Fabre, pode ser assim expressa: se a meditação produz uma ascese, ela o faz na medida em que o homem conseguiu construir um lugar dentro dele mesmo, um lugar de reconhecimento de si. A ideia de reconhecimento aqui é fundamental. É ela que permite a fixação dos valores que fazem a ligação com o processo de identificação, condição necessária para a aderência do praticante do exercício meditativo.

Fabre ressalta a questão do encadeamento, do ordenamento e da repetição das imagens na meditação. Como sabemos, Foucault bem aponta estas características na sua análise do texto meditativo. Ele argumenta que Descartes, apesar de ter dito que os sonhos podem lhe oferecer ilusões mais extravagantes que as ilusões dos loucos, prefere imaginar que está sonhando que estava ali, vendo suas mãos, seu corpo, segurando o papel, enfim, meditando. A alusão não é aleatória. Ela cumpre a função de marcar a contraposição com a situação dos loucos que estão em outro lugar. 


\begin{abstract}
Descartes, mesmo afirmando a grande potência do sonho, não pode dar outros exemplos senão o que vem redobrar exatamente a situação atual do sujeito meditando e falando; e isso de modo que a experiência do sonho simulado pudesse vir alojar-se precisamente nas balizas do aqui e do agora. Em contrapartida, os insensatos são caracterizados como aqueles que se tomam por reis, como os que se creem vestidos de ouro ou que se imaginam ter um corpo de vidro ou ser um jarro. Mais ou menos extravagantes do que o sonho, pouco importa, as imagens da loucura escolhidas por Descartes como exemplos são, à diferença daquelas do sonho, incompatíveis com o sistema de atualidades que o indivíduo assinala falando. $O$ louco está alhures, em outro momento, com um outro corpo e em outras roupas. Ele está em uma outra cena. (FOUCAULT, 2001a, p. 83).
\end{abstract}

A ordem das razões é composta por um encadeamento lógico, demonstrativo, expõe argumentos facilmente identificáveis. Os "acontecimentos discursivos" na ordem da ascese têm que ser rastreados por diferenças semânticas (diversos sentidos de fous) ou encadeamentos de imagens. Foucault diz que se não admitimos esta hipótese não compreendemos a repetição da cena:

\begin{abstract}
A mesma cena é reproduzida três vezes no decorrer desses três parágrafos: estou sentado, tenho os olhos abertos sobre um papel, o fogo está ao lado, estendo a mão. Na primeira vez, ela é dada como certeza imediata do meditador; na segunda, ela é dada como um sonho que, com muita frequência, acaba de produzir-se; na terceira vez, ela é dada como certeza imediata do meditador fazendo de conta, com toda a aplicação de seu pensamento, que é um homem sonhando, de modo que do interior de sua resolução ele se persuade de que é indiferente, para a marcha de sua meditação, saber se está acordado ou dormindo. (FOUCAULT, 2001A, p. 82).
\end{abstract}

Sobre a exclusão da loucura, ela se dá como um tipo de contradição ou contra-senso na ordem do texto. Como se sabe, depois que o sujeito cartesiano encontra sua primeira certeza, e conforme ele vai qualificando-se enquanto sujeito de certezas, as contraprovas dos argumentos da dúvida das percepções sensíveis, dos sonhos, do gênio maligno, vão sendo apresentadas, de forma que, uma vez desdobrado o sistema, aparecem todas as respostas para as questões colocadas pela dúvida. Em contrapartida, no caso da loucura, Descartes menciona de imediato seus mecanismos: "cérebro perturbado e ofuscado pelos vapores da bílis". Parece realmente estranho que "um fragmento antecipado do saber venha ocupar o vazio da prova rejeitada" ou que justamente um discurso que acabara de se colocar como meta buscar um novo fundamento para a ciência, apresente, como justificativa da exclusão de uma hipótese, uma informação "que o saber já localizou, definiu e dominou” (FOUCAULT, 2001a, p. 89).

A loucura teria ganhado este tratamento diferencial porque Descartes não poderia ter explicitado sua exclusão, justamente por ser uma exceção à simetria do sistema, "o momento 
da exclusão da loucura no sujeito em busca de verdade é forçosamente ocultado do ponto de vista da ordenação arquitetônica do sistema" (FOUCAULT, 2001a, p. 88). Esta é a condição de se exercer a dúvida.

\section{Loucos de crer, loucos de duvidar}

Alguns anos mais tarde (1993), alguns intérpretes da filosofia cartesiana envolvem-se num debate sobre a querela, tais como Martial Gueróult, Jean-Marie Beyssade, Ferdinand Alquié e Michelle Beyssade. Dentre eles, destaca-se Ferdinand Alquié que teve o mérito de tentar reformular a questão. No seu entender, o verdadeiro divisor de águas não está na discussão sobre a exclusão da loucura mas na concepção cartesiana de loucura. Focar o problema neste ponto abre nova perspectiva. Alquié afirma que Foucault e Derrida não discorrem sobre exatamente a mesma questão. O que está em desacordo entre os autores não seriam as condições de rejeição da loucura, mas uma divergência no entendimento do que Descartes teria tomado por loucos, daí suas argumentações seguirem caminhos diversos. Segundo Alquié, Foucault tomaria o louco por um alucinado e Descartes rejeitaria compararse com ele porque ele não sabe duvidar, ele é muito seguro. Ou seja, neste caso o louco não pode ser utilizado como modelo porque Descartes não pode comparar-se a quem não duvida. O louco neste caso se engana porque permanece prisioneiro dos sentidos. É "louco de acreditar"(BEYSSADE, JM, 1993, p. 104). Derrida, por sua vez, toma o louco por um delirante, aquele que não se fia de suas sensações, ele as recusa pelo delírio imaginativo. Ele então pode servir de modelo porque coloca a dúvida até a negação dos sentidos, tal qual o meditador faz. No primeiro caso, sensação e imaginação confundem-se, no segundo, estão separadas.

De qualquer modo, o ordenamento das imagens, tratando-se de uma meditação cartesiana, assume importância fundamental. Em relação a este aspecto, uma das singularidades que dá o tom a esta leitura das Meditações, é que Foucault defende que as imagens compõem um encadeamento que dá suporte à ordem da ascese. A exclusão da loucura não é dita mas é mostrada imageticamente. Este gesto duplo não pode ser lido mas está visível. O enunciado é aquilo que é da ordem do saber, a ordem epistemológica. O que resta visível é o que é da ordem da ética, da qualificação moral do sujeito que medita. Mas por que podemos afirmar que a loucura dialoga com a ideia de qualificação moral no século 
XVII? Para responder esta pergunta, é necessário entrar na dupla trama de História da loucura na Idade Clássica, assunto que será discutido a seguir.

\section{Dupla ordem do discurso foucaultiano}

Vimos que a afirmação de uma ordem da ascese é tese controversa. Porém, a questão da ordem das meditações talvez nos oriente a compreender algo do método filosófico foucaultiano. É inegável que são vários os componentes que perfazem a totalidade de seu discurso, ora descritivo, ora dissertativo, ora narrativo, ora trazendo imagens puramente ficcionais. As imagens evocadas em História da loucura dá unidade aos argumentos, compõem os quadros junto com as informações dos arquivos, ao lado de trechos de poesias e descrição de pinturas. Como afirma Pierre Billouet (2003, p. 22-23), em Foucault "as imagens têm função constitutiva (constituir a unidade mental ao juntar a diversidade) ou uma função ilustrativa (manter a atenção ligando os elementos unificados por conceitos)". Neste sentido, o texto de Foucault apresenta igualmente uma dupla trama. Poderíamos usar as mesmas palavras que Foucault utiliza para qualificar o texto cartesiano com relação ao seu próprio texto: "[...] trata-se de um exercício cuja experiência modifica pouco a pouco o sujeito meditador, e de sujeito de opiniões ele se vê qualificado como sujeito de certeza" (FOUCAULT, 2001a, p. 86).

Podemos então nos orientar pela leitura de Deleuze que sustenta que a filosofia foucaultiana se distingue pelo apontamento de visíveis e enunciáveis: “...obcecava Foucault em todas as suas obras: a forma do visível em contraste com a forma do enunciável" (DELEUZE, 2005, p. 42).

Tomemos o exemplo de História da loucura. Foucault aponta que o século XVII criou a categoria dos internos. Ali, em meio à massa indiferenciada, o louco é apenas mais um. $\mathrm{O}$ internamento dos loucos vai se inserir no contexto do internamento dos pobres desempregados e dos associais. $\mathrm{O}$ acontecimento, decisivo na tese apresentada de que antes de se tornar objeto da medicina a loucura fora objeto moral, é por si só um fato importante. Foucault chama atenção de que se trata de um "evento novo" na história, "a invenção de um lugar" onde ocorrerá pela primeira vez uma "surpreendente síntese entre obrigação moral e lei civil" (FOUCAULT, 1978, p. 75).

Foucault insiste também que um fenômeno inteiramente novo como este não se produz 
de uma hora para outra. Para que a internação pudesse ter acontecido de modo massivo foi necessário que tivesse se formado uma nova "sensibilidade social" (FOUCAULT, 1978, p. 55). Trata-se de gestação lenta de uma "nova sensibilidade à miséria". É este o primeiro fator a dar sentido ao ritual da segregação. Até a Idade Média, o sofrimento dos pobres gozava de estatuto místico (religioso e sagrado) e simbolizava a ponte para que o homem probo e de fé pudesse exercitar as boas obras da caridade, provando por este gesto seu amor ou temor a Deus. A partir dos acontecimentos da Reforma e Contra-Reforma, este estatuto aos poucos modifica-se e a pobreza "passa de uma experiência religiosa que a santifica para uma concepção moral que a condena", e o lugar da existência do Hospital Geral "encontra-se no final desta evolução" (FOUCAULT, 1978, p. 59). É esta nova sensibilidade que detonará o processo que culminará na substituição da Igreja pelo Estado e as cidades nos afazeres da assistência aos pobres e desvalidos.

Também nos países protestantes ocorreu este fenômeno que Foucault nomeia oportunamente de "laicização das obras"(FOUCAULT, 1978, p. 58), pois, se doravante as ações de caridade de nada valem mediante a afirmação da fé como critério decisivo de julgamento dos fiéis, o Estado terá de assumir um papel que antes era da Igreja. Os andarilhos desempregados perambulam pelas cidades representando um "obstáculo à ordem”. Entraves ao ordenamento social e da cidade, os loucos agora, junto aos pobres e outros desarrazoados, são problema de polícia. Polícia entendida no sentido de quem deve gerir as intervenções na cidade para manter sua ordem e funcionalidade, daí Foucault afirmar que doravante o destino destas pessoas será decidido com base em "medidas de saneamento"(FOUCAULT, 1978, p. $63)$.

Gerir a cidade moderna é, dentre outras coisas, sanear o espaço público, colocar "fora do caminho" (FOUCAULT, 1978, p. 63) estes que ficam "atropelando-se na cidade", “pedindo esmolas" (FOUCAULT, 1978, p. 67). É nesse sentido que devem ser compreendidas as palavras do édito real de 24/04/1656 que dizem que a atribuição do Hospital Geral era de impedir "a mendicância e a ociosidade, bem como as fontes de todas as desordens" (FOUCAULT, 1978, p. 64).

Quanto ao medo, Foucault chama atenção à formação de uma geografia dos horrores ou dos lugares assombrados simbolizados por espaços de segregação. Diz que os leprosários deram lugar às casas de internamento e estes aos hospitais (FOUCAULT, 1978, p. 72), fazendo girar em torno destes, ainda no século XVII, um imaginário macabro, lugares que 
causam profunda resistência à visitação, associados que estão à circulação dos malditos ${ }^{2}$.

Dizem os arquivos de Foucault, em 1780, que por causa de uma banal epidemia de origem desconhecida, mas provavelmente relacionada à mudança abrupta de clima, formou-se um levante da população que intentava colocar fogo no Hospital de Bicêtre pensando estar ali o foco do problema. É chamada então uma equipe de médicos e profissionais para investigar a causa do problema. Verifica-se que não há nenhum motivo para afirmar que ali havia um foco, pelo contrário, o foco estava fora. E os internos de Bicêtre são inocentados (FOUCAULT, 1978, p. 354). Daí se estima o poder do imaginário do terror, do medo. Mesmo a despeito de tudo o que era enunciado pelos relatórios médicos, era visível que o terror sobrepujava de longe a percepção da epidemia.

Existia um medo "ricochete do internamento", a população era assombrada pelo que se passava dentro dos muros destes lugares. Noutro caso

[...] atribui-se ao escorbuto contágios imaginários, prevê-se que o ar viciado pelo mal corromperá os bairros habitados. E novamente se impõe a grande imagem do horror medieval, fazendo surgir, nas metáforas do assombro, um segundo pânico. A casa de internamento não é mais apenas o leprosário afastado das cidades: é a própria lepra diante das cidades. (FOUCAULT, 1978, p. 353).

Enfim, havia muita confusão neste imaginário que resultava numa “inextricável mistura entre contágios morais e físicos" (FOUCAULT, 1978, p. 356) ${ }^{3}$. Muitos boatos, lendas e histórias sem fundamento real habitavam o imaginário popular, desembocando, esporadicamente, em "toda uma exploração patética" de "temores mal definidos" (FOUCAULT, 1978, p. 354).

Como se observou anteriormente, escolheu-se lançar mão do esquema de Deleuze que indica que a filosofia de Foucault particulariza-se pelo apontamento de visíveis e enunciáveis como forma de chamar as relações ao plano da imanência. Tal abordagem se adequa bem à obra História da loucura, além de permitir que se trace um paralelo com os recursos mobilizados na leitura das Meditações.

De qualquer forma, Foucault mesmo dirá em entrevista nos anos 1970 que a presença

\footnotetext{
${ }^{2}$ Eis um exemplo: "Lepra grande demais para a capital! O nome de Bicêtre é uma palavra que ninguém pode pronunciar sem não sei que sentimento de repugnância, horror e desprezo [...]. Tornou-se o receptáculo de tudo o que a sociedade tem de mais imundo e mais vil". (MERCIER, Tableau de Paris, VIII, p. 1 apud FOUCAULT, M. História da loucura, p. 353).

${ }^{3}$ Esta mistura entre contágios morais e físicos, como se pode imaginar, também foi observada na história brasileira. $C f$ MACHADO, R. et al A Danação da norma: Medicina Social, Rio de Janeiro, Graal, 1978.
} 
de elementos "visíveis" ou o apontar de espacialidades que nos constituem podem ser interpretados como os primeiros passos de um método que se definirá cada vez mais na direção do apontamento das práticas sociais que nos definem enquanto sujeitos. Assim, o apontamento do visível assume toda uma racionalidade, do espaço da fluidez da circulação no Renascimento ao espaço da fixidez e imobilidade na internação. O interessante é que esta situação geográfica desenhada é que nos remete à prática social, não o contrário. E então, o sentido não é determinado por uma reflexão conceitual que abstrai a realidade. Michel Serres já havia feito nos anos 60 uma leitura similar a esta. Diz ele que Foucault resolveu escrever esta História da loucura na linguagem da geometria para poder compor um quadro linguístico e lógico da segregação. Isto porque, como a segregação interditaria o diálogo, a forma da língua escolhida teria que se aproximar do silêncio dos loucos (SERRES, 1962).

Em entrevista à revista Herodote, em 1976, Foucault dirá que utilizava vocabulário espacial porque estes termos denotam uma visão estratégica. Ele diz que as metáforas espaciais o obcecaram porque seu foco naquele momento era descobrir uma forma de chegar na relação saber-poder. Mas não só por isso. Ele queria também se contrapor às análises que tomavam os discursos como continuidade temporal porque levavam à instância de uma consciência geradora (FOUCAULT, 1982).

Existem várias formas de aproximação de Foucault com esses visíveis: pode ser tanto o uso de um vocabulário espacial, uso de um pensamento mais estratégico de poder, a análise de uma paisagem, análise de uma obra de arte, a "pintura" textual de uma obra de arte, a descrição de uma prisão, o apontamento de uma geografia, o apontamento de um fluxo espacial, apontamento de uma dinâmica espacial das relações de poder, de afeto, relações sociais em geral, os conflitos geopolíticos em várias escalas, relações espaciais que constroem subjetividades etc. São objetos e procedimentos muito distintos agrupados sob a categoria dos "visíveis". Trata-se, nesse sentido, de delinear, sugerir, descrever minuciosamente, rascunhar, retratar, incitar a imaginar.

Em História da loucura, muitas paisagens são desenhadas, o muro do Hospital, os grandes muros das cidades, os portões da cidade, os espetáculos de castigo e humilhação dos pobres em praças públicas. Mas ali os enunciáveis ocupavam um local privilegiado também. Foucault diz que "ao lado de tudo o que uma sociedade pode produzir ("ao lado": isto é numa relação assinalável a tudo isto), há formação e transformação de "coisas ditas". É a história destas “coisas ditas" que eu empreendi." (FOUCAULT, 1972b, p. 71). 
Foram os arquivos escritos que fascinaram Foucault e o levaram a querer realizar a pesquisa de sua tese. Diz ele, em 1972, numa entrevista, que estava diante de um material cuja organização era muito fraca do ponto de vista da sistematicidade interna e acuidade conceitual. Mas, por outro lado, e isso o atraia bastante, os discursos institucionais deste conjunto eram muito fortes, prenhes de significações, pois era visível o quanto estes discursos eram "tributários de estruturas sociais, de condições econômicas, tais como o desemprego, as necessidades de mão-de-obra, etc" (FOUCAULT, 1972b, p. 20-21).

Pode-se constatar que não há antagonismo nem dicotomia entre visíveis e enunciáveis. Há uma relação de irredutibilidade entre eles. São instâncias onde se desenrolam jogos de saber e de poder. Trata-se, pois, somente de querer restituir as coisas à sua imanência (DELEUZE, 2005, p. 52) ${ }^{4}$. Com efeito, em História da loucura, a loucura, tal como a via o hospital geral, e a desrazão, tal como a anunciava a medicina, “obcecava Foucault”. Ou seja, “a forma do visível em contraste com a forma do enunciável” (DELEUZE, 2005, p. 42).

Foucault foi o primeiro a observar que nas Meditações, Descartes enunciava que, ao final da primeira jornada meditativa, nada tinha sido salvo pelo exercício da dúvida metódica. Por isso, ele nos faz ver que a reiterada imagem do sujeito meditando mostrava que se tinha salvado um resíduo de verdade, e em contraponto a estas imagens, a imagem do louco como aquele que está em outro lugar, e que não consegue duvidar de si mesmo, mostra que sua presença não cabe no processo meditativo. Assim se qualifica moralmente, o sujeito que medita, visto que no século XVII, a desrazão era vista como uma forma de opção moral. E a sua exclusão, justamente por não se encaixar na ordem das razões do discurso argumentativo, fora interpretada até então como passagem meramente retórica.

Em História da loucura, os loucos, desempregados, delinquentes, associais estavam juntos. Diz Foucault: “o que para nós não passa de uma sensibilidade indiferenciada era com toda a certeza, para o homem clássico, uma percepção claramente articulada" (FOUCAULT, 1978), o que nos faz pensar quais seriam as formas de "invisibilidade" da nossa contemporaneidade.

\footnotetext{
${ }^{4}$ Deleuze também distingue três instâncias correlatas do visível. Na primeira, como no caso do internamento, as forças estão do lado de fora. No segundo caso, agenciamentos concretos, onde se atualizam as relações de força, relativamente aos procedimentos disciplinares. O exemplo mais evidente é o panóptico onde se vê claramente que as relações de poder estão em ato no próprio lugar do agenciamento. Existe outra instância também em que se faz incidir mecanismos de segurança genéricos, numa escala populacional (DELEUZE, 2005, p. 52).
} 


\section{REFERÊNCIAS}

ALQUIÉ, Ferdinand. Le philosophe et le fou. Descartes metafisico: interpretazioni del novecento. Seminario di studi cartesiani, Roma, 1993, p. 107-116.

BEYSSADE, Jean-Marie. Mais quoi ce sont des fous. Revue de métaphysique et de morale, juillet-septembre 1973, Paris, p. 273-294.

BEYSSADE, Jean-Marie. Descartes au fil de l'ordre. Paris: PUF, 2001.ol.III. Rio de Janeiro, Zahar Editores, 1981.

BEYSSADE, Jean-Marie. La querelle sur la folie: une suggestion de Ferdinand Alquié. Descartes metafisico: interpretazioni del novecento. Seminario di studi cartesiani, Roma, 1993, p. 99-106.

BEYSSADE, Michelle. Michel Foucault et Jacques Derrida: y a-t-il um argument de la folie?. Descartes metafisico: interpretazioni del novecento. Seminario di studi cartesiani, Roma, 1993, p. 117-120.

BILLOUET, Pierre. Foucault. Trad. Beatriz Sidou. São Paulo, Estação Liberdade, 2003.

DELEUZE, G. Foucault. São Paulo, Brasiliense, 2005.

DERRIDA, Jacques. Cogito e História da loucura. Trad. Pedro Leite Lopes. In: Ferraz, Maria Cristina Franco (org). Três Tempos sobre a História da loucura, Rio de Janeiro, Relume Dumará, 2001, p. 11-67.

DESCARTES, R. Méditations métaphysiques. Paris: Press Universitaires, 1966.

DESCARTES, R. Discurso do Método. Meditações. As paixões da alma. Cartas. Objeções e respostas. Trad. Bento Prado Júnior e J. Guinsburg. Os Pensadores. São Paulo, Abril Cultural, 1975.

ERIBON, Didier. Michel Foucault 1926-1984. São Paulo, Companhia das Letras, 1990.

FABRE, Pierre-Antoine. Ignace de Loyola: le lieu de l'image. Paris: Vrin-EHESS, 1992.

FOUCAULT, M. Sobre a Arqueologia das Ciências Humanas - Resposta ao Círculo de Epistemologia. In: FOUCAULT, M. Estruturalismo e Teoria da Linguagem. Petrópolis, Vozes, 1971.

FOUCAULT, M. Mon corps, ce papier, ce feu. In: Histoire de la folie à l'âge classique. Posfácio. Gallimard, Paris, 1972, p. 583-603.

FOUCAULT, M.. Resposta a uma questão. Revista Tempo brasileiro, 28, jan-mar 1972 b, p. 57-81. 
FOUCAULT, M. Histoire de la folie à l'âge classique. Gallimard, Paris, 1977.

FOUCAULT, M. História da loucura na Idade Clássica. Trad. José Teixeira Coelho. São Paulo: Ed. Perspectiva, 1978.

FOUCAULT, M. Microfísica do Poder. Org. e Trad. de Roberto Machado. Rio de Janeiro, Editora Graal, 1982.

FOUCAULT, M. Resposta a Derrida. Trad. Vera Lúcia Ribeiro. In: Ferraz, Maria Cristina Franco (org). Três Tempos sobre a História da loucura, Rio de Janeiro, Relume Dumará, 2001, p. 71-90.

FOUCAULT, M. Dits et Ècrits I - 1954-1975, Ed.Gallimard, Paris, 2001 b.

FOUCAULT, M. Dits et Ècrits II - 1976-1988, Ed.Gallimard, Paris, 2001c.

FOUCAUlT, M. A Hermenêutica do sujeito (1981-1982). Trad. Muchail, S.T e Fonseca, M.A. São Paulo, Martins Fontes, 2004.

HADOT, P. O que é a Filosofia Antiga? Trad. Dion Macedo. São Paulo: Loyola, 2004.

MACHADO, R. et al. A Danação da norma: Medicina Social. Rio de Janeiro, Graal, 1978.

SERRES, Michel. Géometrie de la Folie, Mercure de France, n. 1188, août 1962, pg. 683 696 e n. 1189, sept 1962, pg. 63-81. 